\title{
Responses to Peter Manuel's "World Music and Activism Since the End of History [sic]"
}

\section{Political Music, Facts, and Views of Them}

\author{
BEATE KUTSCHKE
}

\section{Facts and the way we respond to facts}

Reading Peter Manuel's article for the first time, I expected to learn primarily about the relationship between musical pieces and socio-political change. Looking at it more closely, I realized that his article is rather on views of musical pieces and views of socio-political change; it is more on ideas, attitudes, emotions, and the spirit that we (and other individuals) attribute to what we consider to be facts than the facts themselves. I will support this viewpoint in the following paragraphs.

Peter Manuel's starting point is the observation that, in the course of the student and protest movements of the 1960s and 70s, a vigorous scene or culture of political music developed around the globe that, since the 1980s, has increasingly vanished. He claims that this disappearance of the scene is related to (or has even been caused by) significant socio-political and economic changes climaxing around 1990: the end of the Cold War and, connected with this, the end of antagonists fighting over the hegemony of their favored economic-political systems (capitalism vs. communism; dictatorship vs. democracy) in the 1990s and, especially after the turn of the millennium, the rise or intensification of new menaces, first and foremost, "an amorphous global financial network" and "savage tribal, religious, and ethnic movements armed with modern weaponry.”

This is the explicit dimension of the text. The kernel of the article's argument, however, is the description of different kinds of spirit that Peter Manuel and other contemporaries (including me!) experience in response to specific historical facts and political music. What is so tricky about this experience of spirit is that we attribute the spirit to the historical facts and political music, and which we attribute to them as if those were their own properties. He points out that the movements of the 1960s and 70 s and the music related to them are marked by a specific spirit or attitude. He describes this spirit as "an underlying invocation of compatible Enlightenment values - that is, essentially liberal, modernist, and universalist conceptions of social justice and human rights, often counterposed to commercialism and economic domination by elites or imperialist hegemons," in sum, "humanism." In the 1960s and 70s, Peter Manuel explains, those values and ideas operated as "secular metanarratives" that served as action imperatives for the movements. To what degree is this description of the movements' spirit significant for the overall argument of the article? As I understand his observations, they are less conclusions from detailed analyses of statements of the members of the political and musical movements than rather a summary of the "impression" he has. In other words, the spirit is a phenomenon that we, the recipients of 
the movements, experience and then attribute to the movements as their property.

This understanding of Peter Manuel's descriptions also influences the overall message of the article. If his portrayal of the strengths of the political and music movements of the 1960s and 70s is an account of the image the movements hold in our view today, it becomes obvious that the weaknesses Peter Manuel observes regarding the political music since the 1980s - in his view: the lack of a similar spirit and emotional arousal-are similarly not properties of the music, but value judgments resulting from our individual experiences while listening to the music. So, in sum, we could say that Peter Manuel's dissatisfaction regarding the political music of the 1980s reflects his attitude toward this music; it does not necessarily say anything about the quality, meaning or effects of the music.

\section{Histories of the idea of the "end of history"}

The mixture of facts and spirits that recipients experience in response to the facts is not only characteristic of Peter Manuel's article but also of universalist historiographies, i.e., the products of historians who claim to reveal the rationality of history as the totality of global changes in all segments of human life: society, politics, and economics as well as culture, religion, science, technique, and medicine.

The crucial role that evaluative attributions to facts play in universal historiographies manifests itself in the history of the diverse ideas of the end of history, one of the key narratives of universal historiographies. The idea of the "end of history" is deeply rooted in Jewish-Christian eschatological thinking according to which human inner-worldly history would end in outer-worldly paradise. During the eighteenth century, the idea of the "end of history" received new nuances of meaning in that enlightenment philosophers such as August Ludwig Schlözer (1772), Isaak Iselin (1786), Marie Jean Antoine Nicolas Condorcet (1793) and Immanuel Kant (1798) transformed the metaphysical concept into a universalist forecast. They suggested that human history would lead to a final state of "paradise on earth." They supported their view by drawing conclusions regarding future development from past history. From the mid-nineteenth century onwards, however, a rather pessimist view replaced the optimistic one. Then, in the twentieth century, a series of humanitarian catastrophes-first and foremost, two world wars, the Holocaust and the development of nuclear weapons-consolidated this pessimist view. With the catchphrase "the end of history," sociologists, philosophers and cultural critics such as Roderick Seidenberg (1950), Hendrik de Man (1951), Theodor W. Adorno (in the early 1950s), Günther Anders (1956), Lewis Mumford (1964) and Arnold Gehlen (1961 and 1972/73) referred to their imagination (and fear) that technical progress and rigorous administrative organization, whose tendencies they were already observing in contemporary societies, would lead to a globally systematized, dehumanized and, therefore, stagnating socio-political and economical system. In this globally-ruling system whose parameters they obviously derived from the observation of especially Western societies, history in the sense of "development" and "change" would be disabled. Last but not least, in the 1980s and 90s the "end of history" was an extremely fashionable philosophical idea that people used in order to sound "cool" and intellectual even if they had no clear idea about what they were talking.

To what degree is this history of the use of the catchphrase "end of history" significant for Fukuyama's thesis and the role it plays in Peter Manuel's article? Seen in the context of the history of the idea of the end of history, Fukuyama's thesis interpreting the victory of capitalism and liberal democracy as the end of history is just another universalist story in the series of diverse stories of the end of history and, as we know today, as fictional and illusionary as those that preceded his thesis (even though he 
differentiated his thesis by discussing objections and contradictions). Emotions, fear, desires, and values shape his perspective on the facts as they shaped the perspectives of his predecessors. Propagating that, after the end of the Cold War, capitalism has defeated communism, Fukuyama's thesis of the early 1990s says less about the world in the 1990s than about how Fukuyama saw and felt about the world at this time: namely quite optimistic.

Honestly, I have always had difficulties with Fukuyama's thesis. In my view, it is obvious that Fukuyama's thesis tells more about his_optimistic_feelings of the world in the 1990s than it helps to understand this world (and human history as a whole). Not only since 9/11 and Al-Qaida, the 2008 financial crisis and ISIS terror, we know that the victory of capitalism that Fukuyama celebrates is not suited to effect eternal paradise on earth. It has always been clear-not just to me, but to numerous critics of Fukuyama-that, even if the radical implementation of communist ideas has turned out to be a catastrophe for humanitarianism, similarly radical capitalism with its now global financial markets is neither the remedy nor the ultimate alternative to communism. Unrestricted capitalism leads to the division of the world in winners and losers, the exploitation of numerous individuals, be it destitute people in non-Western so-called second or third world countries or be it low-income employees or freelancers in Western capitalist countries themselves. And as long as this exploitation goes on, there will be people fighting for justice and-nolens volens—changing the world, i.e., "making history." However, if Fukuyama's thesis does not appropriately describe the world off the 1990s, to what degree is it helpful to understand better the history of political and protest music (as response to socio-political change)?

\section{Whose views? - Western vs. non-Western views of history and politics}

In addition to this skepticism regarding Fukuyama's thesis, I generally wonder whether Western authors on "universal history" are useful sources for what Peter Manuel intends to argue for. Remember that he emphasizes that his focus is not on Western, but non-Western political music. He mentions musicians, pieces, and movements from Latin America, Africa, Near East, and India. This means that if we want to relate those individuals' music and their political "messages" to views on politics whose development political events stimulate, I think we need to reconstruct those individuals' attitudes towards global historical changes, i.e., the attitude of non-Western musicians and their peers, not of Western political scientists such as Fukuyama.

Moreover, I am wondering which significance the regional differences between the various communities of political music and the political perspectives developed in those regions have. Peter Manuel points out the differences (section II), but claims at the same time that they do not question the existence of a general, comprehensive spirit shared by all communities (and their members). In the introduction to Music and Protest in 1968 whose individual chapters on protest music in Europe, Africa, both Americas, and Asia revealed a similarly diverse, by no means coherent picture, I have probably argued in the same way. I underscored the common spirit and, in doing this, decreased the significance of the differences between the various protest movements and protest musics around the globe. From my current perspective, I suppose it would have been more correct if I have had emphasized more the discrepancy between the common spirit I felt in response to the protest and music movements, on the one hand, and the factual differences between the movements, on the other. In this light, the question arises: how complex is the world and to what degree are we justified in condensing heterogeneous historical phenomena to common tendencies? 


\section{The general and the particular: What do we mean by the "sound of the revolt"?}

Regarding music and protest of the 1960s and 70s, there is another phenomenon emerging in the mid-2000s that supports my thesis that the specific spirits Peter Manuel describes (or misses) are not properties that the protest and music movements possess, but an effect of our own mental processes which we attribute to the movements. This example is the discourse on the sound of the revolt."

In 2006 the German filmmaker and writer Oliver Schwabe invented the term "sound of the revolt" with respect to Western popular music of the late 1960s and 70s. The expression appeared spontaneously plausible to many recipients. Otherwise, it would not have soon gained popularity in German discourse. Schwabe's creation of a label is remarkable because, looking at the protest music of the 1960s and 70s more closely, it becomes visible that it is absolutely unclear to what kind of sound individuals refer if they use the term. What can be considered the, i.e., one sound of the revolt if the protest music of those decades is a conglomerate of diverse musical styles, genres, and musicians who have all their own sounds and whose sounds change from moment to moment?

Of course, the problem I have pointed out is just the well-known phenomenon that Wittgenstein called "family relationships," i.e., the phenomenon that we change the criterion of classification while classifying objects and thus end up with classes that contain diverse objects that are dissimilar instead of similar because there is no feature they share with each other altogether. However, regarding the "sound of the revolt" of the 1960s and 70s the lack of such common features is comparatively salient. The sound of the protest song "We shall overcome" that a solo singer-Joan Baez, perhaps-performed in a concert-like setting availing herself of "natural" vocal technique and an acoustic guitar, is significantly different from a protest song performed by a "mass" choir of people (during a protest march, for instance). Although the "I-Feel-Like-I'm-Fixin'-To-Die Rag” that Country Joe McDonald performed during the Woodstock Festival of 1969 has a similar "instrumentation" (solo voice + acoustic guitar + mass choir shaped by the audiences), its sound is quite different: Country Joe articulates the lyrics in a rock-like mumbling manner; the sound of the guitar is rather intrusive and pushy. Not least, the available amplifying system has characteristically shaped the sound. Likewise, "I can't get no satisfaction" and "I am black and I am proud" serving as examples for the musical genres of rock and soul in this context, are marked by a range of diverse and specific sounds resulting from the musical instruments, amplifiers, micro-timing between rhythm section and vocals, idiomatic elements such as shouting (in soul) and the distortion of the e-guitars (in rock), etc.. In sum, the sound of the revolt whose concept appears to German adherents of protest music immediately plausible must be a mental construct as, I have claimed above, the spirit of the movements and their music is a mental construct.

However, if this is the case, doesn't our attribution of a specific spirit to protest music of the 1960s and 70s and our lack of passion regarding later protest movements such as the Arab spring and the Occupy Wall Street movement of 2011 and their musical emblems tell more about our own attitude to those movements and sounds than about the effectiveness and world-changing power of them? Does our enthusiasm for the "sound of the revolt" of the 1960s and 70s perhaps reveal a kind of identification with the agents of the student and protest movements while the active dissenters of the political movements of 2011 have remained rather foreign to us? 


\section{The Unending History of Protest Music}

\section{NORIKO MANABE}

Peter Manuel's article is a tour de force, drawn from decades of personally researching musical cultures in India, Latin America, Spain, and other cultures. It is a testament to his academic versatility and adeptness. Manuel argues that the protest musics that blossomed worldwide in the 1960s and 70s were the product of a global cultural climate, spawned by movements that shared "modernist ideals of secular, liberal, egalitarian justice, and universal human rights" deriving from the "legacy of the Enlightenment." He provides many rich and insightful examples from around the world to support this view. Starting from Francis Fukuyama's conjecture that the triumph of capitalism and democracy over socialism signalled "the end of history," he notes that this change in the global political order has depoliticized popular music. ${ }^{1} \mathrm{He}$ sees the current cultural landscape to be more fractious, with progressive movements being cause-specific rather than transcendent or visionary, while right-wing or militantly tribal movements gain ground.

To Manuel's thought-provoking essay, I pose a few responses. I argue that protest music is still going strong, but in ways different from the 1960s and 70s. The explanatory causes, in my view, are economic and technological. Changes in the music industry, in terms of demographics, monetization, and distribution, have affected what music gets made and heard. In particular, more people around the world discover and listen to music over the internet. Protest music has always been a largely DIY or participatory endeavour; cyberspace has made it even more so, with a proliferation of digitally enabled remixes, mashups, and cutups, as well as contrafacta. Such forms rely on copyrighted material and are not meant for commercial distribution. Furthermore, I agree with Manuel that right-wing or militant music is playing important cultural roles today; I believe that music related to all manner of causes is worthy of investigation, especially today.

\section{Can history end?}

Manuel approaches Fukuyama with caution, and space limits this article from a full discussion of Fukuyama's hotly debated thesis. Nonetheless, I would mention that in arguing for an evolutionary arc of history, Fukuyama's 1989 essay ignored or downplayed many political conflicts that were extant that year-Tiananmen, the anti-apartheid struggle in South Africa, the Levant, racial tensions in the US (as exemplified by Yusef Hawkins's murder), to name a few. Such struggles had grave implications for human rights, and they gave rise to passionate, memorable music. Indeed, 1989 was an important year for protest songs. Chuck D exuberantly shouts, "1989!" at the top of "Fight the Power" - one of the most powerful protest songs of the last thirty years, ${ }^{2}$ played as far away and as recently as in Japanese antinuclear protests in the wake of the Fukushima accident. Songs like Cui Jian's "Nothing to My Name" formed the soundtrack to the Tiananmen protests.

Furthermore, many of the social movements that have arisen around the globe, particularly since

\footnotetext{
${ }^{1}$ Fukuyama, Francis, “The End of History?” The National Interest 16 (1989): 3-18.

2 "Fight the Power" appears as \#10 on a list of the greatest political songs in the New Statesman. "What Are the 10 Greatest Political Songs of All Time?" The New Statesman, May 2015, http://endpointa269dec6.chios.panth.io/ideas/the-10-greatestpolitical-songs/.
} 
2011, demonstrate that the triumph of liberal democracy, as asserted by Fukuyama, is hardly universal, complete, irreversible, or unflawed. This unfulfilled promise is a thread running through the Arab Spring, the Sunflower Movement in Taiwan (2014), the Umbrella Movement in Hong Kong (2014), and the protests against constitutional revision and remilitarization in Japan (2014-15), which argued for more direct sovereignty by individual citizens. A second thread connects the Occupy movement and the protest movements in Iceland, Greece, and Spain in 2011: neoliberalism, i.e., the power of the financial sector and the pain that the financial crisis, resulting recession, and austerity measures inflicted on ordinary people. Opposition to capitalistic greed is also central to the antinuclear movement in Japan or the occupation of Standing Rock; they protest the privileging of energy industries (in conjunction with the government) over concerns for nearby residents' safety or quality of life. These geographically dispersed movements are hence related ideologically, just as the movements of the 1960s-70s may have been; they have also sparked their own musics. Have these songs attained less visibility than the protest musics of the 1960s-70s that Manuel describes, and if so, why?

\section{Changes in the music business}

Part of the answer lies in the structure of the music industry and the demographics feeding it. During the politically galvanizing moments of the late 1960s, the postwar baby boomers constituted a demographic bulge: the number of 15-24-year-olds had grown from 24 million in 1960 to 34.4 million in 1969, or from 13 percent to 17 percent of the population. ${ }^{3}$ The young men of this group-middle-class and poor, white and non-white-were being drafted to serve in Vietnam, giving this age group a strong reason to protest. This demographic group also constituted the sweet spot of the record-buying public. Television and magazine news coverage, which showed the war's brutal impact on civilians, helped to support anti-war sentiment. Furthermore, the legislative victories of the Civil Rights Movement spurred ongoing activism. The environment was ripe for protest songs to sell.

The record industry of the 1960s was well poised to sell into this market. They controlled the intricate channels of retail distribution and the relationships with radio and television broadcasters. Radio stations were not nearly as specialized in the 1960s-70s as they are now: At a time when pop stations were either pop, $\mathrm{R} \& \mathrm{~B}$, or country, top 40 was dominant in listeners' lives in a way that is hard to fathom in today's highly segmented radio markets. Today, stations cater to aging boomers through oldies or classic rock formats, and to multiple ethnicities separated by genre and language. ${ }^{4}$ In addition, television broadcasting in the 1960s was largely concentrated in a few networks. In this environment, record companies could release protest songs and expect them to sell; three examples would be "Say It Loud - I'm Black and I'm Proud" (James Brown, 1968, \#10 on Billboard Hot 100), "Ohio" (Crosby, Stills, Nash and Young, 1970, \#14, Hot 100), and Volunteers (Jefferson Airplane, 1969, \#13, Billboard Pop Albums). Even in the army town of Fayetteville, NC, the anti-war song, "Billy, Don't Be a Hero" (1974), received significant airplay and reached number one on the charts.

Today, the record industry is in a weaker position to influence taste. Revenues from physical unit

\footnotetext{
${ }^{3}$ Center for Disease Control, "Population by age groups, race, and sex for 1960-97," accessed December 28, 2016, https://www.cdc.gov/nchs/data/statab/pop6097.pdf.

${ }^{4}$ Stephen Holden, "Breakup of Pop Music Audience Leaves Top 40 Radio Tuned Out," The New York Times, March 23, 1993, s.v. "News," http://www.nytimes.com/1993/03/23/news/breakup-of-pop-music-audience-leaves-top-40-radio-tuned-out.html.
} 
sales worldwide in 2015 were a third of levels in 2005 (at $\$ 5.8$ billion vs. $\$ 17.9$ billion) and a seventh of peak levels in 1999 ( $\$ 38.7$ billion $)^{5}$. While royalties from streaming services have been growing dramatically (up 45 percent over last year in 2015), they have far to go to make up for this large loss of revenues: in 2015, streaming only accounted for 19 percent of global revenues ${ }^{6}$. Record shops have disappeared; large retail chains like Tower Records are long gone, and destination record stores like Other Music in New York or Cutlers in New Haven have also closed. Broadcast radio, once the primary way of introducing new songs to the public, has fragmented into a myriad of formats: As of 2014, the nearest equivalent of the top-40 format (now called "pop contemporary hit radio") accounted for only 8 percent of US radio stations ${ }^{7}$. While radio remains a mainstay, it may be losing listening time to online radio, which the listener could tailor at will to fit her taste, mood, or lifestyle. ${ }^{8}$ Music buying as a whole has shifted from acquisition to the rental model of subscriptions to streaming services and clicks on YouTube, which are highly individualized and harder to centralize. The net result is that the public's tastes have become atomized (while the monetization has become less lucrative), making it extremely difficult to have a giant hit on the order of Michael Jackson's Thriller (1982).

In such an environment, music companies may have little incentive to take risks with a political song that will inevitably upset those listeners who don't agree with the view presented. Instead, the industry has tended to concentrate on sure-fire blockbusters. In Japan, the idol-pop group AKB48 has achieved great success with its multipronged business model; together with its sister groups, it has edged out practically everyone else (but Johnny's boy bands) on the top-20 charts over the past few years. ${ }^{9}$

In addition, the music industry may actively discourage protest songs. For example, the Japanese entertainment industry operates as if nuclear power were a taboo topic, and there are strong connections among the energy industry, government, and media businesses. In one infamous incident, Toshiba EMI cancelled the release of rock group RC Succession's album Covers (1988), presumably because it contained two antinuclear songs. Furthermore, the music industry censors itself through an industry-sponsored inspection committee, as well as multiple layers of inspection within each record company. Typically, the industry eschews mentioning the names of people or organizations, or topics under national deliberation. Such restrictions would make it impossible to release a protest song like Neil Young's "Ohio" (1970), which names Nixon in the first line. Musicians would need to use highly metaphorical texts or find other distribution channels to express controversial views. ${ }^{10}$

As musicians often pay a price for political engagement, they may withdraw or not participate unless they feel a strong sense of conviction. When a member of the popular Taiwanese band Mayday uploaded the song "Rise Up" to his Facebook page during the Sunflower Movement, rumours circulated that the

\footnotetext{
${ }^{5}$ IFPI, “Global Music Report” (2016), 9; IFPI, “2000 Recording Industry World Sales” (2000), 8.

${ }^{6}$ IFPI, “Global Music Report,” 4, 9.

${ }^{7}$ Nielsen, "State of the Media: Audio Today-How America Listens," March 5, 2015, 14.

${ }^{8}$ While terrestrial radio remains the preferred audio format in the US, used by 91 percent of the population, online radio usage has doubled since 2010 to 57 percent of the population as of 2015. See Nancy Vogt, "Audio: Fact Sheet," Pew Research Center's Fournalism Project, June 15, 2016, http://www.journalism.org/2016/06/15/audio-fact-sheet/.

${ }^{9}$ Of the top-20 best-selling CD singles for 2016 (as of December 26), fifteen were by similar female-idol pop groups managed by the same producer, Yasushi Akimoto (four by AKB48, three by Nogizaka 46, three by Keyakizaka 46, two by SKE48, two by HKT48, and one by NMB48). The five remaining top singles were by boy bands managed by Johnny's Entertainment (three by Arashi, one by SMAP, one by Hey! Say! JUMP). This chart dominance by AKB-like groups has been in place since 2010, while Johnny's has been a chart mainstay for decades. http://www.oricon.co.jp/rank/js/y/2016/p/2/

As of 2016, Japanese charts were based on physical unit sales. A separate ranking was started for downloaded albums only in November 2016. Oricon rankings do not take streaming or YouTube hits into account. http://www.oricon.co.jp/rank/about/ ${ }^{10}$ Noriko Manabe, The Revolution Will Not Be Televised: Protest Music After Fukushima (New York: Oxford University Press, 2015).
} 
band would be blacklisted in the People's Republic of China and banned from Chinese radio; they quickly made explanations and deleted the link. ${ }^{11}$

In the US, a myth has perpetuated that about 75 percent of hip-hop sales are to white audiences, ${ }^{12}$ which Tricia Rose and others have partially blamed for the disengagement from political discourse in commercial hip-hop. ${ }^{13}$ The veracity of these figures has been hotly debated, ${ }^{14}$ and the real, more recent figure may be closer to 47 percent. ${ }^{15}$ Nonetheless, one wonders why commercial recordings about Black Lives Matter (BLM) did not reach mainstream audiences sooner: While the hashtag has existed since July 2013 (following the acquittal of George Zimmerman for killing Trayvon Martin), no BLM-themed recordings were commercially released for some time, even in the wake of outrage in Ferguson (August 2014). By then, Jay-Z had partially written "Spiritual" (2016) but chose not to release it. The more immediate musical responses were free uploads in SoundCloud, like Lauryn Hill's "Black Rage" and J Cole's "Be Free." A commercial recording would not arrive until December 2014, when D'Angelo brought forward the release of Black Messiah after Darren Wilson was not indicted for killing Michael Brown. After Black Messiah and Kendrick Lamar's To Pimp a Butterfly (March 2015) were met with universal acclaim, the floodgates opened for musicians to release BLM-themed material. Could artists or agents have been waiting for confirmation that pro-BLM songs would be acceptable to a broad audience?

\section{A flowering of protest songs, despite}

But my analysis above is likely over-pessimistic. As Jon Pareles recently pointed out, the shift away from single-track iTunes downloads toward streaming may be helping to resurrect the album as a listening format, and with it, greater experimentation by musicians away from radio-friendly pop. ${ }^{16}$ Furthermore, Billboard has been revising its computational methods to include streaming services $(2007,2012)$ and YouTube hits (2013); such revisions may encourage artists to produce some songs that will capture attention by provocation, rather than fitting into pop radio formats.

Despite the above-named impediments, the last three years has seen a flowering of commercially produced protest songs—so much so that several lists of "best protest songs of 2016" have appeared. ${ }^{17}$

\footnotetext{
${ }^{11}$ I thank Lydia Huang, music theorist at Temple University, for alerting me to this story.

${ }^{12}$ See, for example, “As Much as We Like Shakespeare, the Future's Going to Like DMX', Newsweek, June 14, 2001, http://www.newsweek.com/much-we-shakespeare-futures-going-dmx-153813. I thank Hannah Strong (Temple) for alerting me to this controversy.

${ }^{13}$ Tricia Rose, The Hip Hop Wars: What We Talk about When We Talk about Hip Hop--and Why It Matters (New York: Basic Books, 2008), 14-17.

${ }^{14}$ For example, Davey D and Montford separately question the veracity of the numbers and suggest that the perpetuation of this myth has more to do with marketing incentives of radio stations. Davey D, "Is Hip Hop's Audience Really $80 \%$ White?," Hip-Hop and Politics, July 15, 2006, http://hiphopandpolitics.com/2006/07/15/is-hip-hops-audience-really-80-white/.

Christina Montford, "When It Comes to Rap Music, Are White Boys Really Doing All the Buying?," Atlanta Black Star, November 6, 2014, http://atlantablackstar.com/2014/11/06/really-listening/.

${ }^{15}$ A study by Radio and Television Business Report in 2012 showed that about 47 percent of the hip-hop audience was white. "Hip-Hop, Consumers and Retail," Radio \& Television Business Report, March 22, 2012, http://rbr.com/hip-hop-consumersand-retail/.

${ }^{16}$ Jon Pareles, "With Streaming, Musicians and Fans Find Room to Experiment and Explore," The New York Times, December 22, 2016, http://www.nytimes.com/2016/12/22/arts/music/streaming-album-bon-iver-kanye-west-frankocean.html.

${ }^{17}$ See, for example, "The 50 Best Protest Songs of 2016," Village Voice, December 21, 2016, http://www.villagevoice.com/music/the-50-best-protest-songs-of-2016-9473594; “7 Best Rap Protest Songs of 2016," Df Booth, December 14, 2016, http://djbooth.net/news/entry/2016-12-14-7-best-rap-protest-songs-2016; or Danny Schwartz, "The 10 Best Hip Hop Protest Songs Since The Trayvon Martin Shooting," Hot New Hip Hop, July 8,
} 
Radiohead's "Burn the Witch" (2016) features lyrics such as, "This is a roundup /. . We know where you live," and a video ending in the ritual sacrifice of an outsider; it could be read as an allusion to right-wing, nativist ideologies espoused by UKIP and the witch-hunting against immigrants and minorities. After all, the setting of the video-a pristine, all-white English village, depicted in stop-motion animationresembles Trumpton, part of the Trumptonshire trilogy of British children's television series.

BLM has inspired a bumper crop of politically conscious music in addition to the aforementioned $\underline{B l a c k}$ Messiah by D'Angelo and To Pimp a Butterfly by Lamar. A Tribe Called Quest's We Got It from Here ... Thank You 4 Your Service (2016) contains comments on Trump ("Conrad Tokyo") and racism ("Movin' Backwards"), all perhaps best captured in "We the People ...":

All you Black folks, you must go

All you Mexicans, you must go

And all you poor folks, you must go

Muslims and gays, boy, we hate your ways

So all you bad folks, you must go

Also notable along these themes are $A$ Seat at the Table (2016) by Solange, "Chains" (2015) by Usher ft. Nas and Bibi Bourelly, "Glory" (2015) by Common ft. John Legend, "Baltimore" (2015) by Prince ft. Eryn Allen Kane, "Hell You Talmabout" (2015) by Janelle Monaé and Wondaland, "Cry No More" (2015) by Rhiannon Giddens, and "Sandra's Smile" by Blood Orange, to name just a few from a long list.

Some offerings mix BLM messages with rage at Donald Trump's election rhetoric; most memorably, YG \& Nipsey Hussle's "Fuck Donald Trump" gives the refrain a catchy cadence. Indeed, resistance against Trump during the election inspired an entire playlist called 30 Days, 50 Songs, with contributions by Death Cab for Cutie, Lila Downs, and Loudon Wainwright III, among others. Emilio Estefan assembled an all-star cast (including Gloria Estefan, Carlos Santana, Wyclef Jean, and Carlos Vives) for "We're All Mexicans" (2015), pitching it as a positive statement for all Latinos and immigrants. Nor was the outgoing Obama administration immune from criticism: Anohni's Hopelessness (2016) is full of haunting songs about her disappointment in Obama, drone bombs, surveillance, and climate change.

\section{Changes in distribution, and consequently, song types}

Long before these songs had hit Spotify, other protest songs had been circulating in cyberspace for free. YouTube, SoundCloud, and other sites have long provided venues for songs that labels or broadcasters find unviable or unsanctioned. They fulfil the role that cassettes or broadsheets did in previous times, similarly helping to unleash outbursts of creativity. ${ }^{18}$ In addition, cyberspace serves as an alternative channel for live broadcasting: when Prince performed his Rally 4 Peace concert in Baltimore in May 2015, as an antidote to the riots following Freddie Gray's death, Tidal streamed it live, greatly expanding the audience for Prince's message.

Most protest songs in cyberspace follow a different pattern from the original-song model more typical of commercial recordings. When writers decry, "Where are the protest songs?" and recount the glories of the past, they typically focus on folk musicians or auteurs in the model of singer-songwriters like Bob Dylan, Phil Ochs, or Billy Bragg. ${ }^{19}$ But many protest songs do not follow this model. In particular,

2016, http://www.hotnewhiphop.com/the-10-best-hip-hop-protest-songs-since-the-trayvon-martin-shooting-news.22741.html.

${ }^{18}$ Peter Manuel, Cassette Culture: Popular Music and Technology in North India (Chicago: University of Chicago Press), 1993.

${ }^{19}$ See, for example, Jonathan Luxmoore and Christine Ellis, "Not Talkin' Bout a Revolution: Where Are All the Protest 
protest songs on cyberspace often make use of pre-existing materials; their primary goal is the timeliness of the reaction rather than originality, however defined. This recycling of material not only speeds up the process of creating but also makes the song instantly recognizable and memorable. It also provides cultural material for political commentary.

Contrafacta, or the rewriting of lyrics for a pre-existing melody, has historically been a common type of protest song; cyberspace has allowed for a fast dissemination of such contrafacta. For example, Lauryn Hill's "Black Rage" (2012/2014) takes the melody of "My Favorite Things" from Sound of Music and flips its script from white middle-class joys ("brown paper packages tied up with strings") to the oppression of African-Americans ("black human packages tied up in strings"). That she does so, often by changing only a choice word or two (e.g., from "when the bee stings" to "when the beatings"), makes the song all the more memorable. ${ }^{20}$ Similarly, Wesley Stace's "Mr. Tangerine Man” (2016) retains several words from Bob Dylan's "Mr. Tambourine Man” while ranting on Donald Trump's vanity, racist rhetoric, inflammatory tweets, and questionable business dealings. ${ }^{21}$ Video versions of contrafacta often play on the visual style of the borrowed material: "You're a Mean One, Mr. Trump" (College Humor, 2015) adopts the Dr. Seuss visual style and scenes, as well as the music, of "You're a Mean One, Mr. Grinch" (1966). Many contrafacta are contributed by less well-known artists: Throughout the election season, Randy Rainbow uploaded a series of show-tune parodies, such as "GOP Dropout" (after "Beauty School Dropout" from Grease), "Ya Got Trump Trouble" ("Ya Got Trouble," Music Man), and "BRAGGADOCIOUS!: Randy Rainbow Moderates Debate \#1" ("Supercalifragilisticexpialidocious," Mary Poppins). ${ }^{22}$

The digitization of music has also led to a flowering of remixes, mash-ups, and cut-ups as a form of protest music. Many bank on the recognisability of the source material and its incongruity with the source material. ${ }^{23}$ Lucky TV capitalizes on the humour of this incongruity in remixing the second 2016 US presidential debate. This debate seemed especially mean-spirited: Donald Trump had seated four accusers of Bill Clinton in the auditorium and lurked behind Hillary Clinton, making it appear as if he were stalking her. Lucky TV reimagined it as what was the exact opposite of that mean-spiritedness: "I've Had the Time of My Life," the final love duet from the film, Dirty Dancing (1987). It made for much-needed relief.

Mashing up two source materials can also make an argument in itself. In "Grab 'Em By da Pussy" (2016), hip-hop producer Mike Dean mashes up Trump's infamous Access Hollywood tape with the USA Freedom Girls. When the mostly preteen girls sing, "Make America great," he loops "great" continuously over a loop of Trump saying, "Grab "em by the pussy, bitch"; the juxtaposition makes an unsettling comment on the exploitation of women. By this time, the group was suing the Trump campaign.

Cutups are a subgenre of mashups, whereby words from a person's speech are remixed to mean

Songs?,” The Guardian, February 22, 2016. https:/www.theguardian.com/music/2016/feb/22/protest-songs-folk-musicnancy-kerr-martin-carthy.

${ }^{20}$ Music and lyrics can be heard on Hill's website at "Black Rage (sketch)," Ms. Lauryn Hill, August 20, 2014, http://mslaurynhill.com/post/95329923112/black-rage-sketch. While she uploaded the audio a few days after Michael Brown's shooting, she appears to have first drafted the lyrics around 2012. Kory Grow, "Lauryn Hill Dedicates 'Black Rage' Song to Ferguson," Rolling Stone, August 21, 2014, http://www.rollingstone.com/music/news/lauryn-hill-black-rage-newsong-ferguson-20140821.

${ }^{21}$ Wesley Stace, “Mr. Tangerine Man [live]," 30 Days, 30 Songs, accessed December 25, 2016, http://www.30days30songs.com/28.

${ }_{22}$ Randy Rainbow, RandyRainbow.com, accessed December 26, 2016, http://www.randyrainbow.com/.

${ }^{23}$ Ragnhild Brøvig-Hanssen and Paul Harkins, "Contextual Incongruity and Musical Congruity" in Popular Music 31, no. 1 (2012): 87-104. https://doi.org/10.1017/S026114301100047X. 
something completely different from what he or she was saying. A special kind of cutup matches the cutup words to that of a well-known song; a famous example is "Imagine This" (2006), in which CalTV mashes George W. Bush's quotes with John Lennon's "Imagine" to make an anti-war statement. ${ }^{24}$ An example from the US presidential campaign is Derick Watts" "Do You Want to Build a Wall” (2016), a cutup of Donald Trump "singing" a parody of "Do You Want to Build a Snowman" from the Disney film Frozen (2013). But instead of Anna trying to reach out to Elsa, as in the film, Trump effectively shuts out Enrique Peña Nieto.

\section{Music that maximizes participation}

Mashups are part of a participatory culture of interaction among a community. ${ }^{25}$ This participatory ethos also surrounds music in demonstrations, where the goal is not to present an artistic performance per se but to engage as many people as possible. Singing together can form a powerful sense of camaraderie among the participants, and often a familiar song is the easiest way to maximize this participation. An anthem of the Civil Rights Movement, "We Shall Overcome" is perennially performed at protests worldwide, from Japanese antinuclear protests to Ferguson to solidarity marches in the wake of Trump's election. The union song, "Which Side Are You On" (Florence Reese, 1931), also makes frequent appearances in protests, as in one where demonstrators sang, "Justice for Mike Brown," during a performance of the St. Louis Orchestra. A song that has recently become a political anthem is "Do You Hear the People Sing?" from Les Miserables: it inspired protesters occupying three floors in the Wisconsin rotunda (2011) and thousands of protesters occupying the Central district of Hong Kong (2014) to burst into song.

In addition to singalongs, protesters chant slogans in time to drumbeats or EDM beats, as they have done in Japan's antinuclear and anti-remilitarization movements. Protesters also chant rhythmically $a$ cappella; BLM protesters chant Pharrell Williams's hook from Kendrick Lamar's "Alright" (2015). And the chants themselves recirculate back into protest songs: after \#SayHerName became a protest chant, Janelle Monaé $\mathrm{ft}$. Wondaland released a reworking of her song, "Hell You Talmabout" (2015), shouting out the names of black victims of police or racial violence. Ryūichi Sakamoto looped a recording of Japanese antinuclear protesters chanting "Saikadō hantai" (We oppose restarts) in his atmospheric "Odakias" (2012). Furthermore, the simple act of drumming or beating on casseroles is a form of musical protest, helping protesters to feel communal spirit while expressing themselves in sound. ${ }^{26}$ All these musical and sonic activities have played a role in building solidarity and identity among movement participants.

\section{Both sides now}

After devoting most of his essay to causes "animated by shared Enlightenment values of liberal secular humanism," Manuel mentions some songs of what he terms more chauvinist or militant movements. Indeed, liberalism has no monopoly on protest music. Just as YouTube is full of protest songs

\footnotetext{
${ }^{24}$ Meryl Krieger, “The Politics of John Lennon's 'Imagine,” in The Routledge Companion to Remix Studies, ed. Eduardo Navas, Owen Gallagher, and xtine burrough (New York: Routledge, 2014), 374-85.

${ }^{25}$ Eduardo Navas et al., The Routledge Companion to Remix Studies (New York: Routledge, 2014).

${ }^{26}$ Jonathan Sterne, “Quebec's \# casseroles: On Participation, Percussion and Protest,” Sounding Out!, June 4, 2012, https://soundstudiesblog.com/2012/06/04/casseroles/.
} 
for BLM, human rights, or environmentalism, it is also home to white power music, as well as songs specifically against immigrants (to the $\underline{\mathrm{US}}, \underline{\mathrm{UK}}$, or elsewhere), Muslims, Chinese, and other groups. ${ }^{27}$ Furthermore, right-wing causes often adopt or use the same tactics as left-wing ones. Hardbass flashmobs of white nationalists in Europe take over public spaces with dancing to techno, recalling the tactics of the Reclaim-the-Streets protests of the late 1990s and early 2000s. ${ }^{28}$ While hip-hop has often been viewed as a global protest genre for liberal causes, some right-wing rappers exist in Japan, with Arei Raise and Show-K glorifying the military past and advocating for a return to a militarized Japan. But no matter which side you are on, one thing is for certain: protest music, however defined, is alive, whether it be commercially viable or not.

\section{Not the World Making Music, but Music Making the World}

\section{JOHN STREET}

Anything written by Peter Manuel is worth reading, and this article is especially so. To the complex question of how music and political activism interact, he brings a lifetime's study of the musics of the world and a passion for social change. His argument is not simply a profound analysis of global trends, but the product of deeply held beliefs about the power of popular music to move people, and particularly to engage them politically.

His article ranges with daunting authority over many decades and across many continents. It is written with a sense of regret, frustration, and hope about the link between music and politics. It tackles many serious questions, the most central of which is when and how music fuels oppositional movements. Manuel contends that we have seen a decline in politically-engaged popular music, and this is to be accounted for primarily by shifts in the political order. New political currents and new political forms have meant that the context in which protest music once thrived is no longer present.

Drawing to a close a panoramic account of music's place in political activism, Manuel writes about how "the various socio-political movements, with their associated political musical expressions, represented a particular socio-historical moment that has passed, as the main currents of global culture, in all its diversity, have passed." Following, albeit warily, Francis Fukuyama's account of the "end of history," Manuel suggests that wider political trends have "deprived countercultural music of much of its sense of urgency." There are two key claims here. One is about the decline of protest music, the other about its cause.

Certainly, it does look and feel-for those of us who cherish the sounds of sixties' protest—-that the political song is in decline. And indeed, it is a familiar trope of media reporting, in which articles ask "where have all the protest songs gone?" But it is hard to sustain this impression empirically. Where is the

\footnotetext{
${ }^{27}$ Jonathan Pieslak, Radicalism and Music: An Introduction to the Music Cultures of Al-Qa'ida, Racist Skinheads, ChristianAffiliated Radicals, and Eco-Animal Rights Militants (Middletown, Connecticut: Wesleyan University Press, 2015); Benjamin Teitlebaum, Lions of the North: Sounds of the New Nordic Radical Nationalism (New York: Oxford University Press, 2017).

${ }^{28}$ Benjamin Teitlebaum, "Flash Mobs of the Far Right: Hardbass and the Forging of Dissident European Nationalism" in Oxford Handbook of Protest Music, ed. Eric Drott and Noriko Manabe (New York: Oxford University Press), forthcoming.
} 
hard data to chart the decline? Much depends on how we define the "protest," or more broadly the "political" song. And even if we could agree on such a definition, we are still left with the task of measuring the rise and decline of such songs. Do the charts provide an adequate guide to their presence within the public sphere? When we say that a song was "popular," do we simply mean that it sold in large numbers? I suspect not, but if not, then how do we determine the relevant measurement?

My sense is that this is an impossible task, particularly if we want to map change across several countries, let alone one. I think that it will always be a matter of dispute as to whether protest songs are or are not in decline. They may be, but it is not something that we can claim to know for sure.

This leaves the second question: what accounts for the emergence and resonance of the political or protest song? Peter Manuel looks to politics for his answer. It is the political context that determines the role played by music. Countercultural movements provided the context that allowed songs to flourish. And to the extent that they have been replaced by "the proliferation of cause-specific new social movements, or, most palpably, by militant tribalism," so the conditions for politicised music have been lost. More than this, the changed nature of the politics compounds the problem. Writing of Spain's recent history, Manuel asks: "How does one pen a protest song denouncing the credit glut, the real estate bubble ...?"

Manuel's account of the decline of politically engaged music does strike us as plausible. It is almost a commandment of the study of popular music that we see it as responding to the world in which it finds itself. We intuitively embrace the idea that music's changes are exogenous. But maybe they are not. Maybe it is music that changes the world, rather than the other way around. Much recent work in cultural sociology has argued that changes in our expressive forms are driven less by external factors, and more by internal ones. It has to do with artists, fans, and the internal dynamics of the music industry.

If this is the case, and even if political music is in decline, the reason lies not with the changes in wider political processes, but with the musicians and their followers, with how the music industries have shaped our forms of expression. This is not to say that Peter Manuel is wrong in what he says, but that there's more research to be done, and we should be immensely grateful for what he has done in setting our agenda. 